\title{
Iloa ja kamppailua uusiutumisen tähden
}

Ulpukka Isopahkala-Bouret (2005). Joy and Sruggle for Renewal: A Narrative Inquiry into Expertise in Job Transitions. Departement of Education. University of Helsinki.

Ulpukka Isopahkala-Bouret väitteli vuonna 2005 Helsingin yliopiston kasvatustieteellisessä tiedekunnassa aiheena'Joy and Struggle for Renewal: A Narrative Inquiry into Exper tise in Job Transitions.'

Jo työn nimi herätti kiinnostuksen: voiko tutkimus päästä kiinni asiantuntijan sisäisen uudistumisen iloon ja kamppailuun? Voiko tutkimus auttaa käytännön ihmisiä näkemään omaa tilannettaan entistä syvällisemmin? Kun tutkimus vielä oli saatavana sähköisenä väitöskirjana, kysymyksiin oli lähdettävä hakemaan vastauksia.

Käytännöstä käsin kiinnostukseni kohdistui kahteen pääkysymykseen: miten tutkimuksessasaavutetaan ote työelämän muutoksesta konkreettisena kokemuksena, onko kuvaus ymmärrettävä ja koskettava? Toiseksi minua kiinnosti tutkimustapa. Käytännön työssä kukin rakentaa itselleen malleja vastaavista tilanteista ja tulkitsee niitä. Auttaako tutkimus kehittämään omia havainnoinnin ja tulkinnan menetelmiä?

Tutkimuksen kohteena olivat ICT- alan kokeneet ammattilaiset, jotka ovat juuri käyneet läpi työtehtävien suurta muutosta, joka asettaa uusia vaatimuksia ammattitaidolle. Yksi projekti päättyy ja toinen alkaa. Sen vaatimukset ovat erilaiset kuin edellisen, moni pääsee tai joutuu siirtymään uuden projektin johtoon vastaamaan kokonaisuudesta. Miten he tämän kokivat? ICT-alan muutokset ovat nopeita ja tutkittava yritys toimi kansainvälisissä konteksteissa, joten muutoksen varianssia oli odotettavissa. On muistettava, että ICT-ala poikkesi monista muista siinä, että alalle tultiin voimakkaan kiinnostuksen ja harrastuksen kautta eikä tradition painolastia ollut. Itsensä ohjaaminen asiantuntijaksi kasvussa oli ICT-alalla lähtökohtana ja työssä oppimisen ensisijaisuus oli itsestään selvää.

Tutkimuksessa ilmeni, että työntekijät osasivat selittää kaiken tapahtuneen juuri, kuten nykyään kuuluu selittää ja tulkita. He osasivat myös arvioida itseään ja pohdiskella mahdollisuuksiaan. Heidän joustavuutensa nähtiin pitkän kehityskaaren tuloksena.

Lukija vakuuttui siitä, että tutkija on pystynyt rakentamaan luottamuksellisen suhteen haastattelemiinsa inmisiin. Hän oli itse työskennellyt kyseisessä yrityksessä ja tunsi sitä kautta työn luonteen, osasi siitä keskustella ja kuunnella asiantuntijoita. Hän onnistui vakuutta- 
maan tutkittavat siitä, että he voivat kertoa aitoja kokemuksiaan ja arvioida niitä avoimesti. Tutkija oli myös tietoinen siitä, että ihan kaikki ei ole raportoitavissa, kaikesta ei voida keskustella.

Näin lukija pääsi tutkimuksen kautta mukaan tähän jännittävään näytelmään, mitä työpaikoilla nykyään eletään. Tutkija kertoi pyrkivänsä käytännöllisen ja akateemisen tutkimusorientaation yhdistämiseen. Playmetafora tuntui osuvalta kuvaustavalta-olkoon se sitten peliä tai näytelmää tai leikkiä. Osallistuvat rakensivat itsestä tarinoiden kautta muuntautumiskykyisen ja osaavan kuvan.

Narratiiviset menetelmät avautuivat kiintoisalla tavalla varsinkin, kun tutkija kuvasi ajattelun kulun paloiteltuna prosessina suorista lainauksista.

Tutkimuksen kieli tuntui tutulta myös koulutuksen ammattilaiselle. Kieli kuulosti juuri sellaiselta, kuin sen työhuoneissa ja kahviossa kuulee ja mihin itsekin osallistuu. Kehityskeskustelut ovat tosiaan työpaikalla yksi haaste, jossa joustavuus saa hyvää harjoitusta. On oltava sopivan varma, mutta samalla nöyrä ja kehityshaluinen ja altis muutoksille, pitää todistaa, että on kehittänyt työtään vuosittain - tuon pelin on moni jo omaksunut.

Miten muuten voisikaan tavoittaa asiantuntijuuden muutoksen aidossa työelämän tilanteessa, kuin tarjoamalla asiantuntijalle tilaisuuden kertoa siitä, antaa merkityksiä tapahtumille ja kertoa omasta tavastaan päivittää osaamistaan. Keskustelusta eriteltiin kohde, orientoituminen, toiminta, arviointi, ratkaisu ja yhteenveto-samaan tapaan sitä mielessään jäsentää, kun kuuntelee työtoverin kokemuksia ja itse kertoo omistaan. Kertomuksen ja keskustelun kautta rakentui muutoksen logiikka. Merkityksen anto työelämän tapahtumille on ratkaiseva identiteetin rakentamisen väline. Tutkija kuunteli, miten organisaatio puhui inmisten kautta. Työyhteisössä luotiin ne puhetavat ja käytänteet, joilla oli sosiaalisesti hyväksyttyä käsitellä asiantuntemusta.

\section{Kyse myös vallasta}

Arvostan tutkijan rohkeutta fokusoida siihen, mistä kaikesta asiantuntijuuden murroksessa on kysymys. Hän uskalsi puhua myös vallasta; tutkimuksessa asiantuntijuus nähtiin valtaan kietoutuvana sosiaalisena konstruktiona, valta rajasi mukaan pääsevät ja ulkopuolelle putoavat. Uusiutuminen oli kamppailua tunnustuksen saamisesta, kaikki muutos ei ollut yhtä arvostettua. Kukaan ei halua leimautua vanhanaikaiseksi tai muutosvastaiseksi. Valta on aina läsnä ja kyky miellyttää oikein ratkaisee työn jatkuvuuden. Joustavuuden vaatimus meni syvälle. Taistelu jäsentyi kielipelien kautta; ekspertiisi ja manageriaalinen kieli ottivat mittaa toisistaan. Myös kokemus vallan väärästä jakautumisesta ja sitä seuraava asiantuntijan syrjään vetäytyminen tai kyyniseksi ajautuminen tulivat ilmi tutkimuksessa.

Tuloksia valaistiin monipuolisesti kompetenssien kehittämisen, uran rakennuksen ja Human Resource -perinteen kautta. Lukija voi peilata niihin omia käsityksiään ja oppia jotain uutta. Erityisesti jäi mieleen intuition oivaltava käsittely kompetenssien yhteydessä.
Ekspertiisi, ura ja roolimuutos olivat analyyttisiä välineitä narratiivisessa lukemisessa. Lopussa tarkastelut koottiin yhteen. Asiantuntijan sisäisen uusiutumisen ydintapahtumassa tietämyksen ja toiminnan lisäksi ydinkäsitteeksi nousi 'confidence', mikä oli mielenkiintoinen ratkaisu. Se korosti prosessin luonnetta paremmin kuin aiemmin tutut motivaatio tai tahto.

Tutkimus on ajankohtainen ja se tuntuu olevan hyvin totta. Se myös kosketti syvältä: hermeneuttinen ymmärrys ei ole vain metodista vaan ontologista. Se ei ole vain tutkimusta, vaan tapa olla olemassa ihmisenä, olennaista ihmisyyttä (essential part of being human). Tässä mielessä lukijaa ajattelutti korkeasti koulutettujen inmisten taipumus sokeaan konformistisuuteen, mikä saattaajohtaa taitavaan kulissien rakentamiseen ja ylläpitoon. Voimavarat suunnataan näytelmiin, jonka osapuolet joko tietävät tai kuvittelevat olevan välttämätöntä. Näytelmiin voi alkaa myös uskoa ja asettautua itsetyytyväisyyteen ja kuvitelmiin nykyisten saavutusten riittämisestä kauas tulevaisuuteen. Tällöin uusiutumiskyky heikkenee ja unohtuu, kehitys hidastuu tai pysähtyy.

Tässä kuvaamani väitöstutkimus ei ohjannut valheellisiin näytelmiin vaan askelen lähemmäksi totuutta, mikäli nuo ylipäätään ovat erotettavissa. Totuus ja valhe kun osataan asiantuntijapuheessa kietoa toisiinsa niin taitavasti, ettei niiden erittely aina ole edes mahdollista. Ja mikä pahinta: se ei aina tule edes mieleen. 